УДК 346.5 (477)

DOI https://doi.org/10.32837/yuv.v0i1.1578

\title{
В. Грудницький,
}

кандидат юридичних наук, доцент,

доцент кафедри історії та права

ДВНЗ «Донецький національний технічний університет»

\section{ПРОЦЕСУАЛЬНІ ПИТАННЯ РОЗГЛЯДУ СПРАВ ПРО ЗЛОВЖИВАННЯ МОНОПОЛЬНИМ (ДОМІНУЮЧИМ) СТАНОВИЩЕМ}

Ефективність розгляду справ про зловживання монопольним (домінуючим) становищем та об’єктивність прийнятого рішення безпосередньо залежать від чіткого дотримання всіх процесуальних правил.

Процесуальні норми безпосередньо регулюють порядок розгляду справ i $€$ важливим складником конкурентного законодавства України. Вони охоплюють взаємини всіх учасників процесу - заявника, відповідача, третіх осіб та органу Антимонопольного комітету України (далі - АМКУ). Обгрунтованість процесуальних норм забезпечує ефективний захист не тільки правил конкуренції, а й інтересів сторін у ході розгляду заяв або справ про порушення законодавства про захист економічної конкуренції [1, с. 77].

Процесуальні норми законодавства про захист економічної конкуренції зосереджені в розділі VII «Розгляд справ про порушення законодавства про захист економічної конкуренції» Закону України «Про захист економічної конкуренції, Правилах розгляду заяв і справ про порушення законодавства про захист економічної конкуренції, затверджених Розпорядженням АМКУ від 19.04.1994 № 5, і Положенні про порядок проведення перевірок дотримання законодавства про захист економічної конкуренції, затвердженому Розпорядженням АМКУ від 25.12.2001№ 182-р тощо.

Загалом дослідженням проблем розгляду справ про зловживання моно- польним (домінуючим) становищем займалися як вітчизняні, так і зарубіжні науковці: С. Валітов, Ю. Журик, О. Безух, Є. Борзило й інші. Разом із тим додаткового вивчення потребують процесуальні особливості розгляду справ про зловживання монопольним (домінуючим) становищем.

Метою статті є дослідження основних етапів і висвітлення процесуальних питань під час розгляду справ про зловживання монопольним (домінуючим) становищем.

Розгляд AMKУ справ про зловживання монопольним (домінуючим) становищем складається 3 декількох етапів. Так, Ю. Журик виділяє такі стадії розгляду справ (при цьому наголошує, що вони стосуються лише правопорушень законодавства про захист економічної конкуренції):

- подання та розгляд заяви;

- порушення справи;

- службове розслідування у справі;

- розгляд справи;

- прийняття рішення у справі;

- оскарження рішень у справі;

- виконання рішень і контроль за виконанням рішень у справі;

- перегляд рішень у справі [4, с. 81-82].

Безпосередньо аналізуючи процес розгляду справ на практиці, можемо виокремити такі процесуальні дії.

Згідно зі статтею 35 Закону України «Про захист економічної конкуренції, розгляд справ про порушення законодавства про захист економічної 
конкуренції починається з прийняттям розпорядження про початок розгляду справи [5]. Але варто зазначити, що прийняттю розпорядження про початок розгляду справи передує така процесуальна дія, як розгляд заяви.

Заяви про ознаки порушень конкурентного законодавства у справах, підвідомчих адміністративній колегії територіального відділення АМКУ, подаються у відділення за місцем учинення порушення, або за місцем перебування відповідача, або за місцем настання наслідків порушення.

Заяви про порушення в інших справах подаються в АMКУ.

До заяви додаються матеріали, наявні в заявника, якими заявник обгрунтовує свої вимоги.

Заява про порушення конкурентного законодавства розглядається протягом тридцяти календарних днів, а в разі потреби отримання додаткової інформації, яка не може бути надана заявником, термін розгляду заяви може бути подовжений державним уповноваженим, головою відділення на шістдесят календарних днів, про що письмово повідомляється заявникові.

Якщо стосовно відповідача, зазначеного в заяві, уже відкрито справу за вказаними в заяві ознаками порушення, заява може бути приєднана до цієї справи, про що письмово повідомляється заявникові.

Установивши, що заява подана без дотримання зазначених вимог i це перешкоджає розгляду заяви, державний уповноважений, голова відділення залишає заяву без руху, про що письмово повідомляє заявнику й надає йому термін для усунення недоліків.

Наприклад, мешканці будинку звернулися у відділення із заявою, що тепломережа надає їм неякісні послуги, температурний режим у квартирах не відповідає нормам, тому просять зобов'язати тепломережу зробити перерахунок і притягти іï до відповідальності. Проте при цьому заявники не додали до заяви жодного документа, що підтверджує факт надання неякіс- них послуг централізованого теплопостачання як $з$ боку тепломережі, так і з боку житлово-експлуатаційної організації. Такими документами є копії заяв, надіслані в житлово-експлуатаційну організацію й тепломережу, з проханням направити представників для встановлення причини надання неякісних послуг, з відмітками про їх реєстрацію в комунальних службах і відповіді на них; копії актів-претензій, складені й підписані мешканцями будинку, $з$ відміткою про реєстрацію в комунальних службах, у яких зафіксована температура всередині кожної кімнати, період, протягом якого надавалися неякісні послуги; копії документів (квитанціï), що підтверджують оплату за надані неякісні послуги.

У цьому разі відділення залишає заяву без руху.

Потрібно враховувати, що час залишення заяви без руху не зараховується в строк розгляду заяви. У разі невиконання зазначених вимог у встановлений строк заява може бути залишена без розгляду, про що письмово повідомляється заявнику. Якщо заявник відмовився від заяви, вона залишається без розгляду, що не є перешкодою для продовження АМКУ дослідження з питань, порушених у заяві [2, с. 170-171].

Практика розгляду антимонопольними органами заяв про порушення законодавства про захист економічної конкуренції свідчить про те, що найчастіше підставою для залишення заяви без руху $€$ відсутність викладу обставин, якими заявник обгрунтовує свої вимоги. Така ситуація може бути наслідком незрозумілого викладу або неоднозначного формулювання Правил. Іноді в разі залишення заяви без руху вимоги антимонопольних органів щодо усунення недоліків заяви й вимоги надати ту або іншу інформацію розцінюються заявниками як перекладення антимонопольними органами на заявників своїх обов'язків щодо забезпечення доказів. У цьому випадку наслідком цього може бути витребування інформаціі, відсутність якої, на думку заявника, не 
укладається в поняття обставин, якими заявник обгрунтовує свої вимоги. Заявникові необхідно, одного боку, повідомляти, як саме відсутність тієї або іншої інформації перешкоджає об'єктивному розгляду заяви, а з іншого - уточнити, яку саме інформацію повинні містити обставини, що обгрунтовують вимоги заявника [1, с. 77].

У разі відсутності ознак порушення законодавства про захист економічної конкуренції державний уповноважений, голова територіального відділення АМКУ відмовляють у розгляді справи, про що в письмовій формі повідомляють заявника.

Отже, ми бачимо, що, згідно із законом, розгляд справ про порушення законодавства про захист економічної конкуренції починається 3 прийняття розпорядження про початок розгляду справи. Але варто підкреслити, що цьому розпорядженню передує низка інших процесуальних дії. Наприклад, за заявою суб'єкта господарювання про порушення його прав голова територіального відділення АМКУ затверджує план розгляду заяви, де вказуються строк і дії, які потрібно здійснити. Направляється запит інформації до вказаного в заяві відповідача. Після дослідження матеріалів, зібраних під час розгляду заяви, готується подання про початок розгляду справи про порушення законодавства про захист економічної конкуренціі. Також за результатами розгляду заяви направляється відповідь заявникові.

Наступним етапом є засідання адміністративної колегї територіального відділення АMKУ, на якому розглядається проект розпорядження про початок розгляду справи. Після його затвердження направляється лист заявнику 3 інформацією про прийняте рішення. Підписується службове доручення про збирання та аналіз доказів і затверджується план розгляду справи.

Варто підкреслити, що під час розгляду справи орган АМКУ, що уповноважений приймати рішення в цій справі, має право надавати відповідачу рекомендаціі. У разі виконання відповідачем таких рекомендацій і за відсутності обставин, передбачених частиною 3 статті 46 указаного Закону, уповноважений орган АМКУ приймає рішення про закриття провадження у справі.

Якщо під час справи виникли підстави змінити кваліфікацію дій відповідача, орган АМКУ повинен прийняти нове розпорядження про початок розгляду справи за відповідними ознаками порушення. У такому разі розгляд справи, розпочатої згідно з попереднім розпорядженням, підлягає закриттю через недоведення органом АМКУ вчинення порушення за відповідною кваліфікацією.

Якщо встановлено, що як відповідач до участі в справі повинна бути залучена інша особа, органами АМКУ приймається розпорядження про заміну відповідача або про залучення до участі у справі співвідповідачів, про що повідомляються особи, які беруть участь у справі.

За результатами збирання й аналізу доказів у справі уповноваженими особами АMКУ складається подання з попередніми висновками, яке виноситься на розгляд адміністративної колегії АМКУ

Копії подання з попередніми висновками надсилаються сторонам і третім особам.

За результатами розгляду справи в разі доведення вчинення правопорушення проводиться засідання адміністративної колегії АМКУ, де приймається рішення по суті (про порушення законодавства про захист економічної конкуренції та накладення штрафу).

Перед тим, як прийняти рішення по суті, сторонам процесу повідомляється час і місце проведення засідання адмінколегії, на якій вони можуть висловлювати свої міркування. Після винесення рішення його копіі направляються учасникам справи.

Відповідач може погоджуватися 3 рішенням, тоді він підтверджує виконання постанови (наприклад, квитанція про сплату штрафу), а може й заперечувати, у такому разі справа направляється до суду. 
Важливим складником розгляду справ про захист економічної конкуренції є виконання рішення АМКУ.

Кожне рішення антимонопольних органів України має бути виконано в установленому законодавством порядку, тобто реалізоване для досягнення тієї мети, про яку дбала зацікавлена сторона, суб'єкт господарювання, коли зверталася за захистом своїх прав та інтересів до антимонопольних органів. В іншому випадку звернення до антимонопольних органів виявилося б непотрібним і недоцільним [4, с. 111].

Рішення, розпорядження органів АМКУ, голів його територіальних відділень надається для виконання шляхом надсилання або вручення під розписку чи доведення до відома в інший спосіб.

Останнім процесуальним моментом у справі $€$ представлення службової записки про передачу матеріалів до архіву.

Однією 3 гарантій захисту прав суб'єктів господарювання від можливого свавілля діяльності органів АМКУ є можливість перевірки рішень у справах.

Так, рішення, прийняті адміністративною колегією територіального відділення АМКУ, можуть бути перевірені Комітетом чи адміністративною колегією Комітету за заявою осіб, які брали участь у справі, або за власною ініціативою на підставі подання державного уповноваженого Комітету про перевірку рішення. Рішення, прийняті державним уповноваженим, адміністративною колегією Комітету, можуть бути перевірені Комітетом за заявою осіб, які брали участь у справі, або за власною ініціативою на підставі подання голови Комітету про перевірку рішення.

Оскарження рішень антимонопольних органів передбачено статтею 60 Закону України «Про захист економічної конкуренції. Заявник, відповідач, третя особа мають право оскаржити рішення органів АMКУ повністю або частково до господарського суду у двомісячний строк із дня одержання рішення.
Важливою особливістю $є$ те, що прийняття господарським судом до розгляду заяви про визнання недійсним рішення органу АMKУ не зупиняє його виконання, а в разі наявності достатніх підстав господарський суд може зупинити дію рішення органу АМКУ.

Варто відмітити, що, наприклад, у законодавстві $\in C$ позов може бути подано лише на ті рішення, які мають юридично зобов'язуюче значення, а в законодавстві України під дію вищенаведеної статті 60 потрапляють і ті рішення, з яких антимонопольні органи розпочинають процедуру розслідування, тобто розпорядження про початок розгляду справи про порушення законодавства про захист економічної конкуренціi. У цьому випадку заявник може бути позбавлений права на захист в антимонопольних органах [3, с. 204].

Це свідчить про загальну проблему розмежування компетенції між судовими та антимонопольними органами.

На думку С. Валітова, судовий контроль загалом може стосуватися оцінювання доказів, фактів, дотримання процесуальних гарантій розслідування у справах, правової оцінки змісту рішень. В ЄС цей підхід закладений у пункті 2 статті 230 Договору про Європейський Союз. Практика розгляду справ про захист економічної конкуренції свідчить, що найбільш часто причинами для скасування рішень Комісії $€$ процесуальні порушення, ігнорування прав відповідача. Отже, у цьому напрямі здійснюється розширений судовий контроль [3, с. 204].

3 іншого боку, існують певні питання, які пов'язані 3 рішеннями конкурентних органів і не можуть повністю контролюватися судами. Ідеться про оцінювання складних економічних понять, фактів, коли суддя не має жодних підстав уважати, що його рішення краще, ніж рішення спеціалізованого державного органу [3, с. 205].

До таких складних економічних понять, наприклад, належить визначення монопольного становища суб'єктів господарювання, стану конкуренції 


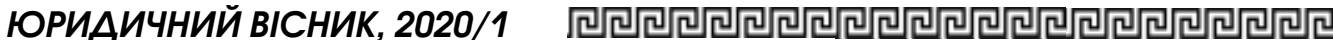

на ринку. Оцінювання цих понять не може бути забезпечено тільки правильним застосуванням методик, для цього потрібно ще й економічна освіта зі спеціальною підготовкою, яка дається в конкурентних відомствах.

На практиці неодноразово виникали ситуації, коли господарський суд удавався до самостійних досліджень ринків товарів, у тому числі товарних і територіальних меж ринків, питань формування цін на ринках товарів тощо, перебравши на себе не притаманні суду й не зараховані до його повноважень функції, які здійснюються виключно органами АМКУ

У зв'язку 3 цим Вищий господарський суд України в порядку інформаціі та для врахування в розгляді справ розіслав господарським судам оглядовий лист, згідно з яким господарські суди у вирішенні спору не повинні здійснювати дослідження ринків товарів, у тому числі товарні Й територіальні межі ринку, питання формування цін на ринках товарів тощо, визначати власними силами монопольне (домінуюче) становище суб'єктів господарювання на ринку, оскільки відповідні функції здійснюються виключно органами АMKУ.

Отже, згідно із законодавством про захист економічної конкуренції, процесуально розгляд справи АМКУ про зловживання монопольним (домінуючим) становищем розпочинається 3 прийняття розпорядження про початок розгляду справи, а закінчується 3 прийняттям рішення по суті. Але як свідчить практика, прийняттю розпорядження про розгляд справи передує така процесуальна дія, як розгляд заяви й затвердження відповідного плану розгляду справи, закінчується непросто прийняттям рішення по суті справи, а виконанням прийнятого рішення. У подальшому матеріали справи направляються до архіву.

Процес розгляду справи завжди супроводжується утвердженням процесуальних документів, які засвідчують про перехід від одного етапу до іншого. Кожна стадія має свою специфіку й відмінності, зміст яких залежать від різних факторів.
У статті досліджуються деякі прочесуальні питання, які пов'язані 3 діяльністю органів АМКУ під час розгляду справ про захист економічної конкуренцї̈.

На прикладі одного з найбільш поширених видів порушення законодавства про захист економічної конкуренції, а саме зловживання монопольним (домінуючим) становищем на ринку, розглянуто порядок дій органів АМКУ під час розгляду справ про порушення законодавства про захист економічної конкуренції.

Установлено, що, згідно із Законом України «Про захист економічної конкуренцї̈, розгляд справ про порушення законодавства про захист економічної конкуренції починається з прийняття розпорядження про початок розгляду справи. Aле, як свідчить практика, прийняттю розпорядження про початок розгляду справи передує така процесуальна дія, як розгляд заяви.

На цьому етапі визначається обтрунтованість претензій заявника щодо порушення його інтересів, розглядаються матеріали, наявні в заявника, якими він підтверджує свої вимоги, вирішується питання наступних дій - залишення заяви без руху чи прийняття рішення про розгляд справи.

У статті наведено приклади відмови в порушенні відкриття справи, як правило, через відсутність достатньої доказової бази з боку заявника. Установлено, що навіть за умови відмови в прийнятті заяви органи АМКУ можуть за власною ініціативою перевірити наявність правопорушень у діях суб’єкта господарювання.

Наступним етапом $є$ рішення адміністративної колегї АМКУ про порушення справи, проводиться збирання й аналіз доказів у справі, за результатом чого складається подання з попередніми висновками.

За результатами розгляду справи у разі доведення вчинення правопорушення приймається рішення по суті, яке може бути оскаржено відповідно до законодавства. 
Важливим етапом є забезпечення виконання рішення АМКУ, оскільки за умови неможливості виконувати рішення Комітету сам прочес розгляду справи втрачає будь-яку доцільність.

3'ясовано, щзо однією з гарантій захисту прав від можливого свавілля діяльності органів АМКУ є можливість перевірки рішень у справах.

Завериується проиес розгляду справи направленням матеріалів до архіву.

Ключові слова: захист економічної конкуренції, зловживання монопольним становищем, розгляд справи, Антимонопольний комітет, процесуальні дії.

Hrudnytskyi V. Procedural issues of case consideration about the abuse of a monopoly (dominant) position

This article explores some of the procedural issues involved in the work of the AMCU bodies in dealing with economic competition.

On the example of one of the most common types of violation of the legislation on protection of economic competition, namely, abuse of monopoly (dominant) position in the market, the procedure of actions of the bodies of the Antimonopoly Committee of Ukraine in considering cases of violation of the legislation on protection of economic competition was considered.

It was found that, in accordance with the Law of Ukraine "On Protection of Economic Competition", the consideration of cases of violation of the legislation on protection of economic competition begins with the adoption of an order to begin the consideration of the case. But, as practice shows, the adoption of an order to commence a case is preceded by such a procedural action as the consideration of the application.

At this stage, the validity of the claimant's claim for violation of his interests is determined, the materials available to the claimant, which he confirms his claims, are considered, the issue of the following actions is resolved - leaving the application without motion or deciding on the case.
The article provides examples of denials of initiation, as a rule, due to the lack of sufficient evidence on the part of the applicant. It has been established that, even if the application is refused, the AMCU authorities may, on their own initiative, check the existence of offenses in the activities of the entity.

The next stage is the decision of the Administrative Board of the AMCU on initiation of the case, the gathering and analysis of the evidence in the case, resulting in the submission of preliminary findings.

As a result of the consideration of the case, upon proving the commission of the offense, a decision is made on the merits, which may be appealed in accordance with the law.

An important step is to ensure the enforcement of the decision of the AMCU, since, if it is impossible to execute the decision of the Committee, the case review process itself loses any expediency.

It is established that one of the guarantees of protection of rights against the possible arbitrariness of the activities of the AMCU bodies is the ability to review decisions in cases.

The process of reviewing the case by submitting materials to the archive is completed.

Key words: protection of economic competition, abuse of monopoly position, consideration of the case, Antimonopoly Committee, procedural actions.

\section{Література}

1. Валітов С.С. Деякі питання удосконалення процесуальних норм конкуренційного законодавства. Правничий часопис Донецьького університету. 2006. № 2. С. 77-82.

2. Валитов C.С., Трегубеи Н.A. Конкурентное право Украины : практикум. Донецк : Юго-Восток, Лтд, 2013. 260 с.

3. Валитов С.С. Правовое регулирование конкуренции в Украине: монография. Донеик : Юго-Восток, Лто, 2009. 307 с.

4. Журик Ю.В. Антимонопольно-конкурентне право України. Київ : Центр учбової літератури, 2011. 272 с.

5. Про захист економічної конкуренизї : Закон України від 11 січня 2001 p. № 2210-14. Відомості Верховної Ради України. 2001. № 12. Cm. 64 . 